Chirurgia (2017) 112: 289-300

No. 3, May - June

Copyright@ Celsius

http://dx.doi.org/10.21614/chirurgia.112.3.289

\title{
Curative Intent Treatment of Hepatocellular Carcinoma - 844 Cases Treated in a General Surgery and Liver Transplantation Center
}

\author{
Răzvan Grigorie', Sorin Alexandrescu', Gabriela Smira', Mihnea Ionescu', Doina Hrehoreț', Vladislav Brașoveanu', \\ Simona Dima', Silviu Ciurea', Patricia Boeți', Ionut Dudus', Nausica Picu', Radu Zamfir', Leonard David',

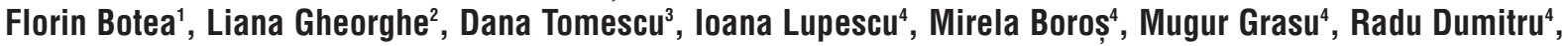 \\ Mihai Toma ${ }^{4}$, Adina Croitoru ${ }^{5}$, Vlad Herlea ${ }^{6}$, Cătălin Pechianu' ${ }^{6}$, Anca Năstase ${ }^{7}$, Irinel Popescu' \\ "Dan Setlacec", General Surgery and Liver Transplantation Center, Fundeni Clinical Institute, Bucharest, Romania \\ 'Gastroenterology Department, Fundeni Clinical Institute, Bucharest, Romania \\ ${ }^{3}$ Anesthesiology and Intensive Therapy Department, Fundeni Clinical Institute, Bucharest, Romania \\ ${ }^{4}$ Radiology Department, Fundeni Clinical Institute, Bucharest, Romania \\ ${ }^{5}$ Oncology Department, Fundeni Clinical Institute, Bucharest, Romania \\ ${ }^{6}$ Pathology Department, Fundeni Clinical Institute, Bucharest, Romania \\ ${ }^{7}$ Biotechnology Department, Fundeni Clinical Institute, Bucharest Romania
}

Corresponding author:

Sorin Alexandrescu, MD, PhD

"Dan Setlacec" Center of General Surgery and Liver Transplantation

Fundeni Clinical Institute, Bucharest Soseaua Fundeni, 258, sector 2

E-mail: stalexandrescu@yahoo.com

Abbreviations:

AFP - Alpha-fetoprotein

CT - computed tomography

FLR - future liver remnant

HCC - hepatocellular carcinoma

$\mathrm{LR}$ - liver resection

LT - liver transplantation

$\mathrm{MRI}$ - magnetic resonance imaging

POD - postoperative days

PVE - portal vein embolization

RFA - radiofrequency ablation

TACE - transarterial chemoembolization

US - ultrasound examination

Received: 21.04.2017

Accepted: 15.05.2017

\section{Rezumat \\ Tratamentul curativ în carcinomul hepatocellular - 844 cazuri tratate în Centrul de Chirurgie Generală și Transplant Hepatic}

Obiectivul acestui studiu este acela de a evalua rezultatele pacienților tratați pentru hepatocarcinom $(\mathrm{CHC})$ intr-un centru de Chirurgie Generalã şi Transplant Hepatic.

Material şi metode: Acest studiu retrospectiv include 844 pacienți diagnosticați cu CHC şi tratați chirurgical cu intenție de radicalitate. Singurele metode de tratament curativ pentru CHC, la ora actualã sunt reprezentate de rezecția hepaticã $(\mathrm{RH})$ şi transplantul hepatic (TH). Ablația tumoralã poate fi indicatã în tratamentul CHC precoce, în cazurile la care rezectia sau transplantul hepatic nu se pot efectua. La 518 pacienți s-a practicat rezecție hepaticã, 162 au beneficiat de transplant hepatic, iar 164 pacienți au fost tratați prin distrucție cu radiofrecvențã (RFA). 615 pacienți (73\%) au prezentat cirozã hepaticã.

Rezultate: Morbiditatea şi mortalitatea înregistrate pentru întreg lotul de pacienți au fost de $30 \%$ şi respectiv $4,3 \%$. Supraviețuirea la 5 ani a fost de 39\% cu diferențe semnificative statistic între pacienții la care s-a practicat RH comparativ cu cei transplantați şi 
cei radioablați $(p<0.05)$, cu rezultatele cele mai bune înregistrate în cazul grupului cu $\mathrm{TH}$, urmate de grupul cu RH şi apoi de grupul cu RFA.

Concluzii: În cazul CHC apãrut pe ficat normal sau non-cirotic, tratamentul de elecție este rezecția hepaticã. În cazul CHC precoce, dezvoltat pe fondul cirozei hepatice, TH oferã cele mai bune rezultate în ceea ce priveşte supraviețuirea la distanțã şi supraviețuirea fãrã recidivã. RFA poate fi consideratã metoda de tratament curativã în cazurile de CHC precoce la care nu se poate practica rezecție hepaticã sau transplant.

Cuvinte cheie: carcinomul hepatocelular, cirozã hepaticã, rezecția hepaticã, transplantul hepatic, distrucția cu radiofrecvențã

\section{Abstract}

Background: The objective of this study is to assess the outcome of the patients treated for hepatocellular carcinoma (HCC) in a General Surgery and Liver Transplantation Center.

Methods: This retrospective study includes 844 patients diagnosed with HCC and surgically treated with curative intent methods. Curative intent treatment is mainly based on surgery, consisting of liver resection (LR), liver transplantation (LT). Tumor ablation could become the choice of treatment in HCC cases not manageable for surgery (LT or LR). 518 patients underwent LR, 162 patients benefited from LT and in 164 patients radiofrequency ablation (RFA) was performed. 615 patients $(73 \%)$ presented liver cirrhosis.

Results: Mordidity rates of patient treated for $\mathrm{HCC}$ was $30 \%$ and mortality was $4,3 \%$ for the entire study population. Five year overall survival rate was $39 \%$ with statistically significant differences between transplanted, resected, or ablated patients $(p<0.05)$ with better results in case of LT followed by LR and RFA.

Conclusions: In HCC patients without liver cirrhosis, liver resection is the treatment of choice. For early HCC occurred on cirrhosis, LT offers the best outcome in terms of overall and disease free survival. RFA colud be a curative method for HCC patients not amenable for LT of LR.

Key words: hepatocellular carcinoma, cirrhosis, liver resection, liver transplantation, radiofrequency ablation

\section{Introduction}

Hepatocellular carcinoma (HCC) is the most frequent primitive liver tumor. It is the $6^{\text {th }}$ most prevalent cancer in the world $(1,2)$, with more than 700000 cases diagnosed yearly (2). The second most common cause of cancer related death is liver cancer, accounting for 745,000 deaths/year, after lung cancer with 1.6 million deaths/year (3). Tumor incidence varies significantly, depending on geographical location. Asia and Saharan Africa constitute high- risk areas, exceeding 20 cases/ 100000 population, because of high incidence of hepatitis B virus (HBV) infection. Southern Europe and Japan have intermediate rates, and rates are low in North America and Northern Europe (3). More than $80 \%$ of HCC patients present with liver cirrhosis. Less than $20 \%$ of these patients present with resectable tumors either because tumor related factors (such as local extension of the tumor, multicentric HCC), or because of the advanced liver disease (4), which affects liver function. Actual treatment of HCC is represented by curative treatment (LR, LT and RFA), local control or bridging therapy that includes RFA, TACE and in some cases LR (before LT), and palliation therapy consisting of targeted therapy, chemotherapy and radiotherapy (5). HCC is an aggressive tumor, therefore the treatment 
should also be aggressive and sometimes patients need bridging therapy or adjuvant therapy in order to increase the efficacy of curative treatment. Currently there is no treatment approved for adjuvant therapy of the HCC. The use of Sorafenib, as adjuvant therapy in STORM trial did not significantly affect recurrence free survival or overall survival $(6,7)$. Sorafenib is indicated only for advanced disease. In patients that did not respond to Sorafenib, the use of Regorafenib seems to be more efficient, therefore FDA approved it as a second line therapy of advanced $\mathrm{HCC}(8,9)$.

In this article, we discuss only about the roles of curative intent treatment therapy (LR, LT ) and RFA and the outcome resulted after performing these therapies, represented by mortality and morbidity rates, survival rates and disease free survival rates.

\section{Patients and Methods}

The targeted population included 844 consecu- $^{-}$ tive HCC patients who underwent curative intent treatment (LT, LR and RFA) in our center between 2001 and 2016. HCC patients diagnosed with advanced forms of HCC, either preoperatively or postoperatively were excluded. We recorded demographic data of the population study including sex, age, etiology of the liver disease, presence and severity degree of cirrhosis using Child score and MELD score for transplanted patients. We also recorded tumor characteristics such as size, number, Milan criteria, Edmonson Steiner grading and tumor. There is no universally accepted staging system. Staging systems for treatment allocation must consider tumor extension and severity of underlying liver function impairment. The BCLC staging system for HCC is the most widely used in western countries, particularly for treatment allocation (10). Patients were staged using BCLC system. BCLC stage B included patients without cirrhosis or with Child A or B cirrhosis with one lesion greater than $5 \mathrm{~cm}$ or 2-3 tumors (of which at least one was greater than $3 \mathrm{~cm}$ ) in absence of vascular invasion or extrahepatic spread $(11,12)$. The preoperative assessment of the tumor and liver function was performed. Patients were assessed performing usual liver function tests such as transaminase levels, cholestasis tests, protein and cholesterol levels, renal function tests and coagulation. Viral and tumoral markers were also recorded. Alpha-fetoprotein (AFP) determination was useful not only for orienting the diagnosis but also for postoperative follow-up of the recurrence. Colonoscopy and superior digestive endoscopy were performed routinely, in order to rule out a metastatic tumor. Imaging assessment of the tumor was performed using ultrasound examination (US), computed tomography (CT) and magnetic resonance imaging (MRI). Some patients with large tumors required liver volumetry in order to estimate future liver remnant (FLR). All patients received and signed an informed consent before surgery. The diagnosis of HCC was formulated after pathologic examination of the resected/ biopsied specimen.

\section{Curative Intent Treatment}

\section{Liver Resection}

The aim of liver resection is to remove the entire portal landmark of tumoral liver, within oncological margin of minimum $1 \mathrm{~cm}$ and to preserve as much liver parenchyma as possible to avoid postoperative liver failure. Brisbane terminology was used for defining different types of liver resection (13-17).

Liver resection is the treatment of choice in HCC patients with non-cirrhotic or normal liver, but only $15 \%$ of HCC occur on noncirrhotic livers. Generally patients present with a single large tumor $>10 \mathrm{~cm}(18,19)$. The size is bigger than in cirrhotic liver because of both delayed diagnosis and also of different mechanisms of hepatocarcinogenesis (18). In HCC occurred on non-cirrhotic or normal liver, FLR should be over $25 \%-30 \%$, in order to perform a safe liver resection.

For cirrhotic patients, liver resection is indicated in compensated cases (Child A cirrhosis and rarely in Child B). In cirrhotic patients, tumors are detected earlier due to regular screening resulting in diagnosing smaller 
tumors. A residual volume of at least $40 \%$ must remain, in order to avoid postoperative liver failure (20).

For carefully selected patients, presented with large tumors considered unresectable at diagnosis, a two-stage surgical approach, often using hypertrophy following portal vein embolization (PVE), can provide a curative option (21). The first step of surgical approach is embolization of portal vein that nurture the tumoral liver, resulting atrophy of the tumoral liver and redirecting of portal flow to the FLR, resulting in hypertrophy of the non-tumoral liver. This is indicated for patients with normal liver or with mild cirrhosis. In the second stage, if the FLR is enough to prevent postoperative liver failure, the patient can undergo a safer liver resection.

\section{Minimally Invasive Liver Resection}

This type of surgery must follow entirely the principles of classic liver resection When feasible, it has the potential to overcome the burden of open surgery, and consequently to improve early outcomes. The advantages are represented by: small incisions, lesser physiological stress, decreased need for blood transfusion and lower hospital stay without affecting oncologic outcome (22). Some of the disadvantages of the laparoscopic surgery are limited degrees of freedom for manipulation, fulcrum effect against the port, tremor amplification, awkward ergonomics, and two-dimensional imaging adaptation (23). Robotic surgery overcome these disadvantages of laparoscopic surgery and keeps the advantages of laparoscopy. It allows surgeons to be in a seated position and offers three-dimensional imaging, and more range of motion.

Although minimally invasive surgery is indicated in small tumors, in experienced hands major liver resection are possible. Daniel Cherqui published first series of major liver resection in 2000 (24). A review on robotic liver surgery revealed that major hepatectomies such as right hepatectomy were performed only in specialized centers; 33 out of 51 right liver resections were performed by Giulianotti and his team $(25-27)$.

\section{Liver Transplantation}

In patients with small HCC, liver transplantation offers a disease-free survival that is better than after liver resection, and similar to the survival of liver transplantation for benign liver disease (28). The target of liver transplantation is aimed not only to remove the tumor burden but also to entirely remove the diseased, cirrhotic liver, and change it with a normal/functional liver. The criteria for deciding if a patient is eligible for LT are very heterogeneous. However, Milan criteria (MC) remain the most frequently used for patient selection (2). LT was performed using whole graft livers (from cadaveric donor or from living donor in case of domino technique), and partial livers (living donor LT or split liver transplantation in case of cadaveric donors) (17,29-31). In order to expand the donor pool marginal donors could be accepted with good results. The use of marginal donors may be related with an increasing incidence of primary non function, but on long run these organs can led to an outcome similar to the one resulted after transplantation with optimal grafts $(32,33)$. Hypothermic oxygenated machine perfusion can be used for improving marginal grafts, before being transplanted (32).

\section{Ablative Therapy}

Ablative therapy can be divided into chemical ablation and energy- based ablation. The representative chemical ablation uses ethanol injection. Energy-based ablation includes RFA, microwave ablation, cryoablation, and irreversible electroporation. For the present time, RFA is the preferred method of ablation, using hyperthermia to destroy tumoral tissue $(34,35)$. Cryoablation uses hypothermia for inducing tumoral necrosis. The future may be represented by electroporation because this procedure is safer than the above mentioned, as it induces apoptosis of the tumoral cells, without damaging vascular elements of the liver parenchyma and theoretically leads to lower morbidity and better results $(36,37)$.

Some authors suggest that RFA is a curative treatment for HCCs under $3 \mathrm{~cm}$ with 4 years survival rate over $65 \%(38,39)$. 
RFA was performed in an operating room, under general anesthesia using percutaneous, laparoscopic, or open surgical techniques. For percutaneous or laparoscopic approach of tumors located in difficult position (segment VIII), we performed also a hydrothorax or pneumothorax in order to facilitate the placement of the RFA needle. The Cool-tip ${ }^{\mathrm{TM}} \mathrm{RF}$ ablation system was used for RFA ablation $(17,35)$.

\section{Bridging Therapy}

According to Kim, transarterial chemoembolization (TACE), RFA and LR, can be considered as treatment methods used for local control and bridge to transplantation.

TACE is a heterogeneous treatment with delivery of different drugs (doxorubicin, cisplatin, epirubicin, mitoxantrone, mitomycin) with different embolizing agents (gelatine sponge particles, polyvinyl alcohol particles, starch microspheres, embospheres, etc.) with or without lipiodol which together form a medium that traps and concentrates the agents within the tumor (5). A new local therapy that emerged from TACE is doxorubicin-eluting beads TACE (DC beads) in which embolization particles are loaded with Doxorubicin that are gradually released and lead to lumen occlusion and ischemia. This procedure resulted in decreased side effects and increased response.

RFA could be used as local control of the HCC patients waiting for LT. LR could be used as first line of therapy before LT in patients in whom pathologic examination reveals an aggressive tumor.

For statistical analysis we used MannWhitney $\mathrm{U}$ to compare quantitative variables. A $\mathrm{p}$ value below 0.05 was considered to be statistically significant. Morbidity rate represented any complication occurred during hospital stay or within 30 postoperative days (POD).

Any death that occurred during hospitalization or within 30 POD was recorded and reported as mortality rate. Chi-square test or Fischer exact test were used to compare the mortality and morbidity rates between the LR, LT and RFA group of patients. Also a p value below 0.05 was considered to be statistically significant.
Population study group was followed until occurrence of death or in cases of survivor, until January 2017 (the end of observation). Follow up after curative treatment consisted of monitoring AFP levels and US exam at 1, 3 and 6 months post operatory and after that, they were screened every 6 months. In addition, CT scan or MRI was performed yearly after that.

The survival rate was defined as the interval between curative treatment applied and the end of observation or patient decease. Patients that were included for calculating mortality rate were excluded.

Disease free survival rates was defined as the interval between curative treatment and detection of HCC recurrence or the end of observation time in patients in whom the disease didn't recur. 1, 3 and 5-year survival, median survival and disease free survival were calculated with Kaplan- Meyer test.

The survival rates between different groups of patients were compared with Log-rank test. When the $\mathrm{p}$-value was lower than 0.05 , the difference was considered statistically significant.

\section{Results}

The clinical characteristics of the 844 patients treated for HCC are summarized in Table 1. The majority of study population was male $(71 \%)$ and the mean age was 59 (ranging from 8 to 83). We divided the patients in three groups according to the type of treatment (LR group, LT group and RFA group). LR patients were significantly younger than LT or ablated patients $(p<0.005)$. Underlying liver disease was mainly cause by HCV infection followed by HBV infection. For LT patients the main cause of cirrhosis was HBV or HBV+HDV infection. Cirrhosis was present in $615(73 \%)$ of patients. Only 57\% of LR patients presented cirrhosis, while for the transplanted or ablated groups, cirrhosis was present in over $95 \%$ of patients. As many authors claim, LR is the treatment of choice for patients with $\mathrm{HCC}$ on normal or non-cirrhotic liver or for patients with Child A cirrhosis. In our study, $86 \%$ of all 297 cirrhotic resected patients presented Child A cirrhosis. 
Table 1. Patient demographics and tumor characteristics

\begin{tabular}{|c|c|c|c|}
\hline $\begin{array}{l}\text { Population study } \\
(\mathrm{N}=844)\end{array}$ & $\begin{array}{r}\mathrm{LT} \\
(\mathrm{N}=162)\end{array}$ & $\begin{array}{r}\text { LR } \\
(\mathrm{N}=518)\end{array}$ & $\begin{array}{r}\text { RFA } \\
(N=164)\end{array}$ \\
\hline \multicolumn{4}{|l|}{ Sex } \\
\hline Male & $115(71 \%)$ & $367(71 \%)$ & $114(70 \%)$ \\
\hline Female & $47(29 \%)$ & $151(29 \%)$ & $50(30 \%)$ \\
\hline Age & 62 & 54 & 61 \\
\hline \multicolumn{4}{|l|}{ Liver disease/infection } \\
\hline $\mathrm{HBV}$ & $34(21 \%)$ & $112(22 \%)$ & $31(19 \%)$ \\
\hline $\mathrm{HCV}$ & $52(32 \%)$ & $199(38 \%)$ & $94(57 \%)$ \\
\hline $\mathrm{HBV}+\mathrm{HDV}$ & $61(38 \%)$ & $18(<1 \%)$ & $13(<1 \%)$ \\
\hline $\mathrm{HBV}+\mathrm{HCV}$ & $2(<1 \%)$ & $0(<1 \%)$ & $9(<1 \%)$ \\
\hline $\mathrm{HBV}+\mathrm{HDV}+\mathrm{HCV}$ & $1(<1 \%)$ & $1(<1 \%)$ & $3(<1 \%)$ \\
\hline Alcohol & $5(<1 \%)$ & $12(<1 \%)$ & $3(<1 \%)$ \\
\hline Other & $4(<1 \%)$ & $3(<1 \%)$ & $13(<1 \%)$ \\
\hline \multicolumn{4}{|l|}{ Cirrhosis } \\
\hline Present & $156(96 \%)$ & $297(57 \%)$ & $162(99 \%)$ \\
\hline Absent & $6(4 \%)$ & $221(43 \%)$ & $2(1 \%)$ \\
\hline \multicolumn{4}{|l|}{ Child } \\
\hline A & $20(13 \%)$ & $255(86 \%)$ & $100(61 \%)$ \\
\hline$B$ & $119(76 \%)$ & $38(13 \%)$ & $64(39 \%)$ \\
\hline C & $17(11 \%)$ & $4(1 \%)$ & 0 \\
\hline \multicolumn{4}{|l|}{ BCLC } \\
\hline 0 & $19(12 \%)$ & $30(<1 \%)$ & $13(<1 \%)$ \\
\hline$A$ & $79(49 \%)$ & $195(38 \%)$ & $111(68 \%)$ \\
\hline$B$ & $35(22 \%)$ & $239(46 \%)$ & $40(24 \%)$ \\
\hline C & $12(<1 \%)$ & $54(10 \%)$ & 0 \\
\hline$D$ & $17(1 \%)$ & 0 & 0 \\
\hline $\begin{array}{l}\text { MELD score } \\
\text { (median value) }\end{array}$ & $13(S D \pm 5)$ & - & - \\
\hline AFP (median value) & $13(S D \pm 2030)$ & $23(S D \pm 4515)$ & $32(S D \pm 670)$ \\
\hline \multicolumn{4}{|l|}{ Tumor } \\
\hline Single & $120(74 \%)$ & $445(86 \%)$ & $135(82 \%)$ \\
\hline Multiple & $52(26 \%)$ & $73(14 \%)$ & $29(18 \%)$ \\
\hline \multicolumn{4}{|l|}{ Milan } \\
\hline Within & $110(74 \%)$ & $231(45 \%)$ & $125(76 \%)$ \\
\hline Outside & $52(36 \%)$ & $287(55 \%)$ & $39(24 \%)$ \\
\hline \multicolumn{4}{|l|}{ Grading/Edmondson- Steiner } \\
\hline Well differentiated & $15(<1 \%)$ & $52(1 \%)$ & $5(<1 \%)$ \\
\hline Moderately differentiated & $90(56 \%)$ & $439(85 \%)$ & $18(1 \%)$ \\
\hline Poorly differentiated & $5(<1 \%)$ & $27(<1 \%)$ & $8(<1 \%)$ \\
\hline NA data & * & 0 & $139(85 \%)$ \\
\hline
\end{tabular}

For advanced stages of cirrhosis (Child B and few cases of Child C) liver transplantation was the treatment of choice.

According to BCLC classification the majority of LT and RFA patients were in stage A, while for LR group most patients were in stage A or B. Although the guidelines EASLD
(European Association for the study of Liver Disease), and AASLD (American Association for the study of Liver Disease) $(10,40)$ do not recommend LR for stage B/C, many authors proposed that LR can be safely performed in these patients (41-44).

MELD score was used for listing the patients for LT and calculated only for patients that underwent LT. Median MELD score was 13 ranging from 6 to 38 .

Median AFP level for the entire study group was $20 \mathrm{ng} / \mathrm{ml}(\mathrm{SD} \pm 3590)$, ranging from $1 \mathrm{ng} / \mathrm{ml}$ to $60940 \mathrm{ng} / \mathrm{ml}$.

In 52 patients diagnosed before LT, with HCC and afterwards underwent bridging therapy for LT, the histology report of the transplanted liver didn't confirm the HCC. This situation could explain the efficacy of bridging therapy for these patients, offering the same outcome as for patients transplanted for non-malignant disease.

\section{Operative Procedures}

Liver resection was performed in an anatomical fashion in 149 (29\%) of LR group of patients and in the remaining 369 (71\%), LR were non anatomical. The various types of LR were presented in Table 2.

Minimally invasive LR was performed in 22 patients from whom 15 underwent laparoscopic LR and 7 robotic LR. In 4 patients we performed right portal vein ligation before hepatectomy. 23 patients with recurrent disease required an iterative LR.

Table 2. Type of liver resection used to treat HCC (LR group)

\begin{tabular}{lrrr}
\hline $\begin{array}{l}\text { Liver resection } \\
\text { (Type) }\end{array}$ & $\begin{array}{r}\text { Cirrhosis } \\
(\mathbf{N}=\mathbf{2 9 7})\end{array}$ & $\begin{array}{r}\text { Non cirrhosis } \\
(\mathbf{N}=\mathbf{2 2 1})\end{array}$ & $\begin{array}{r}\text { Total } \\
(\mathbf{N}=\mathbf{5 1 8})\end{array}$ \\
\hline Right hepatectomy & 7 & 30 & 37 \\
\hline Left hepatectomy & 9 & 11 & 20 \\
\hline Right trisectionectomy & 1 & 10 & 11 \\
\hline Left trisectionectomy & 1 & 3 & 4 \\
\hline Right posterior sectionectomy & 1 & 0 & 1 \\
\hline Left lateral sectionectomy & 43 & 28 & 71 \\
\hline Segmentectomy & 4 & 0 & 4 \\
\hline Bisegmentectomy & 1 & 0 & 1 \\
\hline Non anatomical resection & 232 & 137 & 369 \\
\hline Bisbane terminology
\end{tabular}

Brisbane terminology was used in defining the type of liver resection(14) 
Liver transplantation was the type of curative treatment used for 162 patients. Whole graft LT was performed in 134 patients and 28 patients received living donor LT with right lobe and one pediatric patient recived segment II and III harvested from the mother. One transplant was domino and one split. Milan criteria were fulfilled by 110 patients (74\%). Bridging therapy in waiting for LT was performed in 78 patients. TACE was used in 56 patients, 10 were ablated with RFA and in 9 patients LT was performed after a previous hepatectomy for HCC.

RFA was used to treat 164 HCC patients. The approach was percutaneous in 20 patients, in 128 patients laparotomy was performed and laparoscopic RFA was performed in 16 patients. 79 patients $(48 \%)$ presented with tumors of maximum $3 \mathrm{~cm}$ in diameter. Complete ablation was registered in 68 patients (41\%).

\section{Mortality and Morbidity}

Morbidity rate was $55 \%$ in LT group. The majority of complications were represented by abdominal collections, hemorrhagic events, arterial and portal complications, biliary complications, immunosuppression neurotoxicity and acute rejection.

Mortality rate for LT group was 8\% (13 out of 164 transplanted patients). The main cause of death among transplanted patients was sepsis in 11 cases, and primary non function in 2 cases.

When referring to liver resection, morbidity rate was $24 \%$. The majority of complications were represented by abdominal collections, biliary complications, liver failure hemorrhagic events, pulmonary complications

Mortality rate in case of $L R$ was 3,8\% (20 out of 518 resected patients). The main cause of death among LR group was liver failure in 13 patients, pulmonary complications in 3 cases, 2 cases of sepsis and pancreatitis and coronary event in one case each.

Morbidity rate in RFA group was $12 \%$. The main complications were liver abscess, ascites, hemorrhagic events and pulmonary complications.

In RFA group, mortality rate was 1,2\% (2 out of 164 patients). One patient died from a complicated liver abscess and the other from a superior digestive hemorrhage.

\section{Survival Rates and Disease Free Survival}

Survival rates for the entire study group at 1,3 and 5 years were $81 \%, 56 \%$ and $39 \%$ respec- $^{-}$ tively (Fig. 1).

For transplanted group, LR group and RFA group of patients 1,3 and 5 years survival rates are presented in Table 3. Best survival rates were registered among transplanted patients, followed by resected patients. The differences between each of the three groups of patients were statistically significant $(\mathrm{P}<0.0001)$ (Fig. 2).

In the LR group survival rates were statistically significant, better for non cirrhotic patients $(\mathrm{P}<0.05)$. 1,3 and 5 years survival rates for non cirrhotic patients were $82 \%, 57 \%$ and $41 \%$ respectively and for cirrhotic patients the survival rates were $77 \%, 53 \%$ and $34 \%$ (Fig. 3)

In RFA group, survival rates were statistically significant better for patients with tumors of maximum $3 \mathrm{~cm}$ when compared with patients in whom RFA ablation was performed for HCCs larger than $3 \mathrm{~cm}$, with median survival of 56 months and 29 months respectively $(\mathrm{P}<0.005)$ (Fig. 4)

1,3,5 years survival rates for patients with tumors of maximum $3 \mathrm{~cm}$ treated with RFA were $84 \%, 57 \%$ and $43 \%$ almost identical with survival rates calculated for LR group.

\section{Survival proportions: Survival of Data 1}

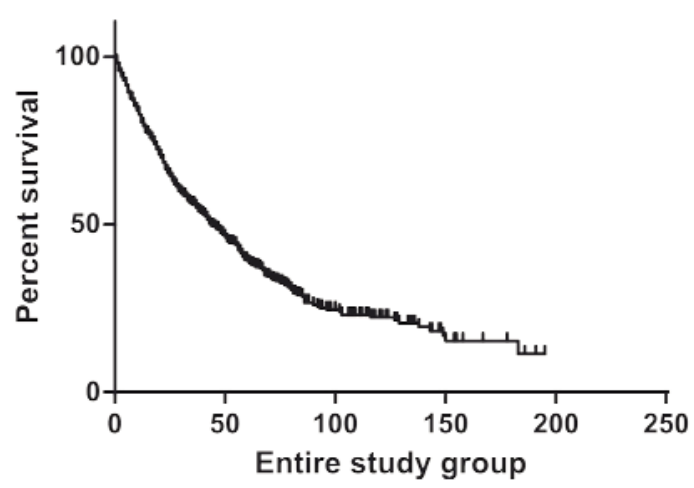

Figure 1. Overall survival of the entire study group 
Table 3. 1, 3 and 5 years survival rates according to each treatment type

\begin{tabular}{lccc}
\hline Survival & LT group & LR group & RFA group \\
\hline 1 year & $90 \%$ & $82 \%$ & $84 \%$ \\
\hline 3 years & $75 \%$ & $55 \%$ & $46 \%$ \\
\hline 5 years & $73 \%$ & $37 \%$ & $25 \%$ \\
\hline
\end{tabular}

Disease free survival at 1,3 and 5 years were for LT group was $83 \%, 75 \%$ and $73 \%$ respectively (Fig. 5). For resection and RFA group we don't have enough data to calculate disease free survival proportions.

\section{Discussion}

The different treatment option for HCC patients must be tailored to each patient according to patient status, liver function evaluation and tumor characteristics.

Survival proportions: Survival of Data 1

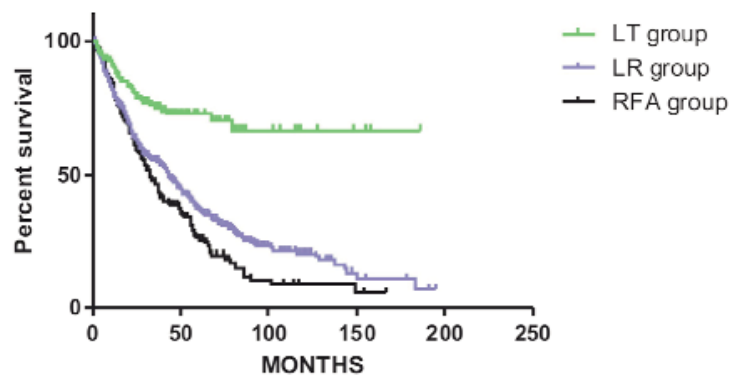

Figure 2. Comparative survival according to the type of the treatment $(p<0.0001)$

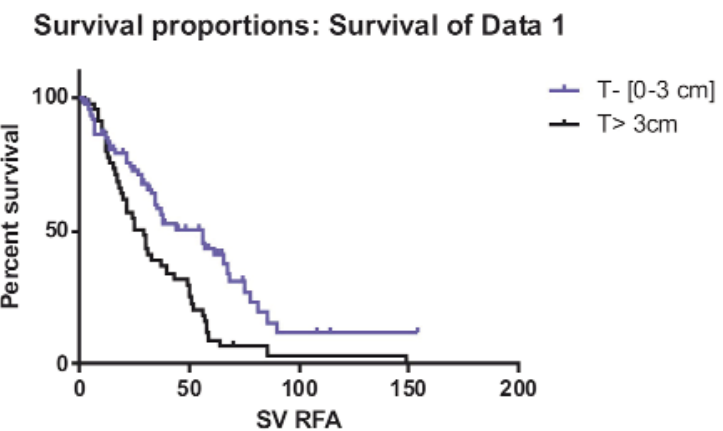

Figure 4. Comparative survival in RFA group according to tumor size $(p<0.005)$
Curative treatment is the main goal, of HCC treatment, but only few patients (10$15 \%)$ with HCC are fit for this kind of treatment at diagnosis $(4,45)$, therefore persistent screening of "at risk" patients is mandatory for early diagnosis.

As previously discussed, HCC occur mainly in cirrhotic patients and similarly, in our study $73 \%$ of patients presented liver cirrhosis. The main cause of cirrhosis was represented by HCV followed by HBV infection, similar to Western model and different from the Asiatic model where HBV infection is the main cause of HCC on cirrhosis (46).

The choice of treatment for HCC depends mainly on the extent of disease therefore LR should be the first option for non-cirrhotic patients or patients presenting mild cirrhosis (Child A), while LT should be the first option for patients with decompensated cirrhosis

Survival proportions: Survival of Data 1

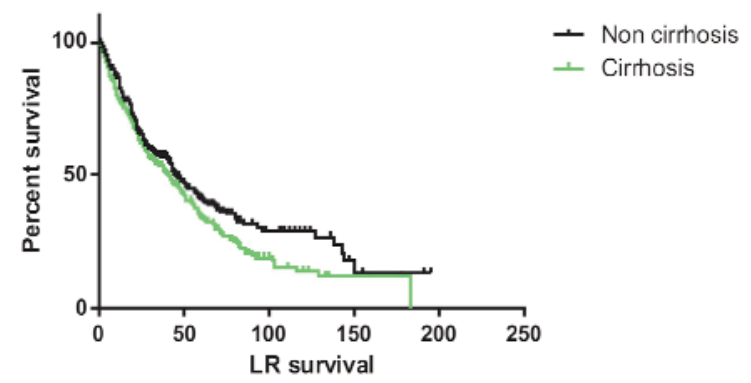

Figure 3. Comparative survival in LR group according to the presence/absence of cirrhosis $(p<0.05)$

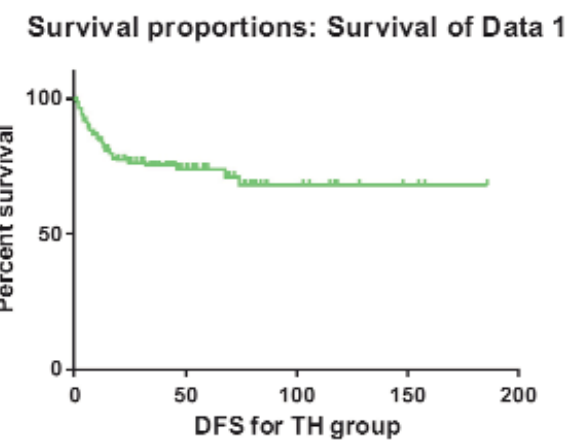

Figure 5. Comparative survival in RFA group according to tumor size $(p<0.005)$ 
(Child-Pugh C) (47,48). According to Barcelona Clinic Liver Cancer (BCLC) staging and treatment allocation for HCC, RFA is considered as a curative method for early HCC.

Nowadays, BCLC staging system is frequently applied in Western guidelines. Although BCLC is accepted in western countries, many Asian- pacific experts do not fully agree with its principle because has very strict guidelines for treatments and only early and very early stage of HCC are fitted for curative treatments (BCLC stage 0 and A) $(10,49,50)$. However, in our study patients that received curative treatment were situated mainly in BCLC A and B classes. For more advanced BCLC (C and D) stages only 83 (1\%) patients out of 844 received curative intent treatments.

According to Kinoshita, currently there is no globally accepted system for assessing HCC patients and the clinician involved in HCC treatment should use currently available staging systems while understanding their features and limitation (51).

The choice of liver resection type should be based on preserving as much liver parenchyma as possible and respecting the oncologic principles (at least $1 \mathrm{~cm}$ of tumor free margin).

Although anatomic liver resection is theoretically superior to non-anatomic, from the oncologic and anatomic aspects, some authors suggest that the type of resection (anatomic vs non-anatomic) doesn't affect the survival or the risk of recurrence $(52,53)$.

In this study, $71 \%$ of liver resection were non anatomical. The vast majority of anatomic resection was performed on non-cirrhotic patients. Preserved liver function of the non- cirrhotic patients permits, anatomical, wide resection, without significant mortality and morbidity (18,54). Morbidity among non cirrhotic LR patients was $25 \%$, bigger that the morbidity registered in cirrhotic patients $(23 \%$ morbidity rate). This fact could be possible because the rate of major hepatectomy was significantly higher than in cirrhotic group (38\% vs $7 \%$ respectively). Although morbidity was higher in non- cirrhotic resected patients, mortality was $2,7 \%$, lower than that registered among cirrhotic patients, and this fact could explain that a cirrhotic patient present an additional mortality risk factor represented by the liver disease.

Despite of the fact that some authors described poor outcome after liver resection for HCC on normal liver, others claimed that LRs performed to these patients could result in better overall survival and disease-free survival than in cirrhotic patients with HCC $(54,55)$. Our group of LR patients confirms these claiming as survival rates registered for non cirrhotic patients were significantly better than those achieved after LR on cirrhotic patients ( $\mathrm{p}-0.038)$ (Fig. 3).

Surgical resection offered as first line of therapy could be followed by liver transplantation in two possible settings. In the first scenario, LT is performed in patients in whom HCC recurred after liver resection and this is called salvage transplantation. The second possibility refers to rescue transplantation, when transplantation is performed for patients in whom resected specimen reveals an aggressive tumor with high risk of recurrence, even when HCC didn't recur (22). In our study a total of 9 patients benefited from LT after a LR performed as first line of therapy.

Liver transplantation not only treats the tumor burden, but also removes the liver disease and theoretically prevent potentially liver failure associated with liver resection (22). The major limitation of liver transplantation is shortage of organs that leads to increased waiting time on the list. Improved survival and lower rates of recurrence are achieved when Milan criteria are met. In our LT group of patients 110 patients (74\%) fulfilled MC. Some authors reported LT beyond MC with similar good results (1-year and 5-year survival rates of $90 \%$ and $75 \%$, respectively), but the further the distance over MC, the higher is the price traduced in survival rates (56). The major benefit of LT compared to LR is the lower recurrence rate (22). Similarly to Yao observation, in our study survival rates were significantly better for patients transplanted within MC than those transplanted outside $\mathrm{MC}(\mathrm{P}<0.05)$ (Fig. 6). Although LT offers lower recurrence rate, morbidity and mortality rates could exceed those resulted after LR. In our study 
Survival proportions: Survival of Data 1

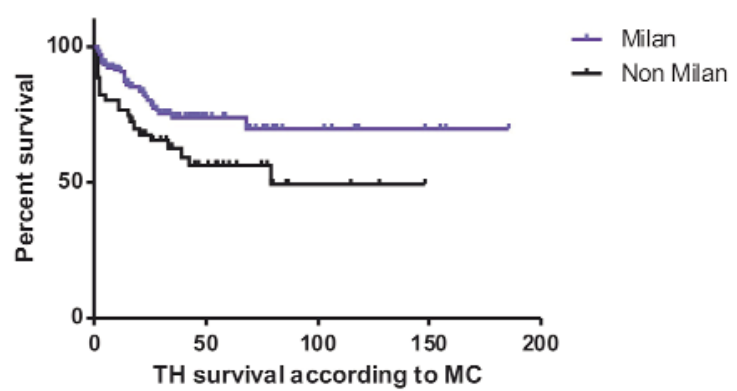

Figure 6. Comparative survival in $\mathrm{TH}$ group by Milan criteria $(p<0.05)$

morbidity was $55 \%$ and mortality $8 \%$ versus $24 \%$ morbidity and $3,8 \%$ mortality.

In order to freeze tumor progression or even to downstage malignancy, some procedures are available. This, so called, bridging therapies were presented previously. Similar survival rates were observed in patients transplanted with and without bridging therapy $(\mathrm{P}>0.05)$ (Fig. 7)

In early HCC, RFA is a desirable treatment option when resection or transplant is precluded or delayed (57).

According to Kim, RFA is considered a therapy used for local control of HCC, but Chen demonstrated in a randomized control study, that percutaneous RFA give similar overall and disease-free survivals as surgical resection for patients with solitary and small HCC $(5,58)$.

This procedure can be performed safely using percutaneous, laparoscopic or open operative approach. The benefits of percutaneous or laparoscopic approaches are those that they are less invasive than open procedure. However open procedure present the advantage of a better visualization of the tumor, possibility of performing Pringle maneuver that enhances the efficacy of RFA and it is easier for performing multiple applications.

The best results are achieved for tumors no larger than $3 \mathrm{~cm}$, although some authors consider these methods viable for larger tumors $(58,59)$. In our series survival rates were significantly better for patients with

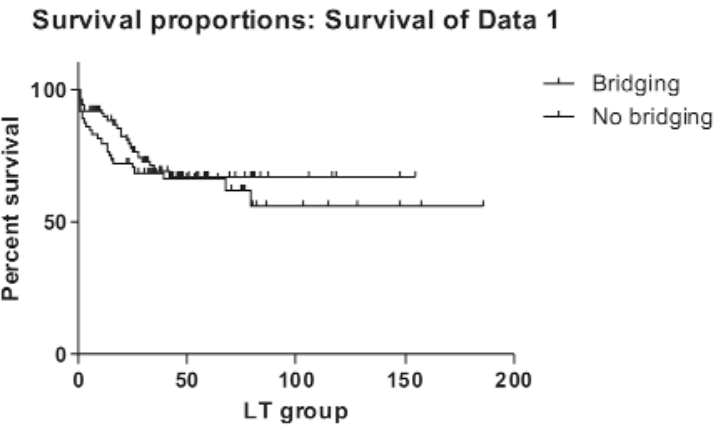

Figure 7. Comparative survival in $\mathrm{TH}$ group by bridging therapy $(P>0.05)$

tumor diameter of maximum $3 \mathrm{~cm}(\mathrm{p}<0.05)$ (Fig. 4).

In our RFA group 79 (48\%) patients presented HCCs of maximum $3 \mathrm{~cm}$. The largest tumor size was $10 \mathrm{~cm}$. Association between RFA and TACE increase survival and decreased recucrrence rate. TACE is the preferred single treatment procedure in downstaging protocols but association with RFA seems to downstage patients better than TACE alone (55).

The goal of RFA should be complete necrosis of the tumor revealed during the procedure by using US examination and afterwards in CT scan. Complete necrosis was achieved in 68 patients $(41 \%)$. This procedure is not an anodyne one, literature data suggests morbidty rates under $10 \%$ and mortality under $0.5 \%$ (59). In our series morbidity was $12 \%$ and mortality rate was $1.2 \%$.

\section{Conclusion}

In conclusion the treatment of HCC is complex and requires a multidisciplinary team. Surgery is the only curative option and should be performed whenever is possible. Liver resection is the treatment of choice for HCC occurred on non-cirrhotic liver, or on mild cirrhosis and can be considered as first line therapy before liver transplantation when recurrence occur or when histology report show high probability of HCC reccurence. Liver transplantation is the best treatment for early HCC and offers best oncologic response and treat the liver disease. RFA 
could be considered a curative treatment in early HCC cases, not manageable for resection or liver transplantation.

When choosing the adequate treatment for HCC, one should take into consideration not only the tumor burden, but also the severity of underlying liver disease, patient performance status and available resources.

\section{References}

1. Forner A, Llovet JM, Bruix J. Hepatocellular carcinoma. Lancet Lond Engl. 2012;379(9822):1245-55.

2. Bruix J, Gores GJ, Mazzaferro V. Hepatocellular carcinoma: clinical frontiers and perspectives. Gut. 2014;63(5):844-55.

3. Ferlay J, Soerjomataram I, Dikshit R, Eser S, Mathers C, Rebelo M, et al. Cancer incidence and mortality worldwide: sources, methods and major patterns in GLOBOCAN 2012. Int J Cancer. 2015 ;136(5): E359-386.

4. Meric F, Patt YZ, Curley SA, Chase J, Roh MS, Vauthey JN, et al. Surgery after downstaging of unresectable hepatic tumors with intra-arterial chemotherapy. Ann Surg Oncol. 2000;7(7):490-5.

5. Kim RD, Reed Al, Fujita S, Foley DP, Mekeel KL, Hemming AW. Consensus and Controversy in the Management of Hepatocellular Carcinoma. J Am Coll Surg. 2007;205(1):108-23.

6. Bruix J, Takayama T, Mazzaferro V, Chau G-Y, Yang J, Kudo M, et al. Adjuvant sorafenib for hepatocellular carcinoma after resection or ablation (STORM): a phase 3, randomised, double-blind, placebocontrolled trial. Lancet Oncol. 2015;16(13):1344-54.

7. Zhong J-H, Du X-K, Xiang B-D, Li L-Q. Adjuvant sorafenib in hepatocellular carcinoma: A cautionary comment of STORM trial. World J Hepatol. 2016 Aug 18;8(23):957-60.

8. Bruix J, Qin S, Merle P, Granito A, Huang Y-H, Bodoky G, et al. Regorafenib for patients with hepatocellular carcinoma who progressed on sorafenib treatment (RESORCE): a randomised, double-blind, placebo-controlled, phase 3 trial. The Lancet. 2017; 389(10064):56-66.

9. FDA Approves Regorafenib for Liver Cancer [Internet]. OncLive. [cited 2017 May 24]. Available from: http://www.onclive.com/webexclusives/fda-approves-regorafenib-for-liver-cancer.

10. Bruix J, Sherman M. Management of hepatocellular carcinoma: An update. Hepatol Baltim Md. 2011;53(3):1020-2.

11. Jianyong L, Lunan $\mathrm{Y}$, Wentao W, Yong Z, Bo L, Tianfu W, et al. Barcelona Clinic Liver Cancer Stage B Hepatocellular Carcinoma: Transarterial Chemoembolization or Hepatic Resection? Medicine (Baltimore). 2014;93(26):e180.

12. Zhong J-H, Xiang B-D, Gong W-F, Ke Y, Mo Q-G, Ma L, et al. Comparison of Long-Term Survival of Patients with BCLC Stage B Hepatocellular Carcinoma after Liver Resection or Transarterial Chemoembolization. PLoS ONE [Internet]. 2013 Jul 9 [cited 2017 May 14];8(7). Available from: http://www.ncbi.nlm.nih.gov/pmc/ articles/PMC3706592/

13. Strasberg SM. Nomenclature of hepatic anatomy and resections: a review of the Brisbane 2000 system. J Hepatobiliary Pancreat Surg. 2005;12(5):351-5.

14. The Brisbane 2000 Terminology of Liver Anatomy and Resections. HPB 2000; 2:333-39. HPB. 2002;4(2):99-100.

15. Popescu I, Câmpeanu I. Surgical anatomy of the liver and liver resection. Brisbane 2000 Terminology. Chirurgia (Bucur). 2009; 104(1):7-10. Romanian

16. Popescu I, Ionescu M, Ciurea S, Brasoveanu V, Sârbu-Boeti $P$, Hrehoret $D$, et al. Current treatment of hepatocellular carcinoma. Analysis of a series of 123 cases over a 5-year period. Chirurgia
(Bucur). 2005;100(4):321-31. Romanian

17. Dima So, lacob S, Botea F, Matei E, Dorobanfu B, Vasile S, et al. Multimodal treatment of hepatocellular carcinoma: an eastern European experience. Hepatogastroenterology. 2009;56(96):1696703.

18. Trevisani F, Frigerio M, Santi V, Grignaschi A, Bernardi M. Hepatocellular carcinoma in non-cirrhotic liver: A reappraisal. Dig Liver Dis. 2010;42(5):341-7.

19. Hepatoma in the Noncirrhotic Liver [Internet]. PubMed Journals. [cited 2017 May 14]. Available from: https://ncbi.nlm.nih.gov/labs/ articles/2843280/

20. European Association For The Study of The Liver, European Organisation For Research And Treatment Of Cancer. EASL-EORTC clinical practice guidelines: management of hepatocellular carcinoma. J Hepatol. 2012;56(4):908-43.

21. May BJ, Madoff DC. Portal Vein Embolization: Rationale, Technique, and Current Application. Semin Interv Radiol. 2012;29(2):81-9.

22. Fonseca $\mathrm{AL}$, Cha $\mathrm{CH}$. Hepatocellular carcinoma: $\mathrm{A}$ comprehensive overview of surgical therapy. J Surg Oncol. 2014;110(6):712-9.

23. Kitisin K, Packiam V, Bartlett DL, Tsung A. A current update on the evolution of robotic liver surgery. Minerva Chir. 2011;66(4):281-93.

24. Kluger MD, Xu EX. Professor Daniel Cherqui: my experiences with laparoscopic liver resection. Hepatobiliary Surg Nutr. 2015;4(6): 422-5.

25. Giulianotti PC. Totally Robotic Right Hepatectomy: Surgical Technique and Outcomes. Arch Surg. 2011;146(7):844.

26. Giulianotti PC, Coratti A, Sbrana F, Addeo P, Bianco FM, Buchs NC, et al. Robotic liver surgery: Results for 70 resections. Surgery. 2011;149(1):29-39.

27. Ramesh H. Resection for Hepatocellular Carcinoma. J Clin Exp Hepatol. 2014;4(Suppl 3):S90-6.

28. Bismuth H, Chiche L, Adam R, Castaing D, Diamond T, Dennison A. Liver resection versus transplantation for hepatocellular carcinoma in cirrhotic patients. Ann Surg. 1993;218(2):145-51.

29. Popescu I, Ionescu M, Brasoveanu V, Hrehoret D, Matei E, Dorobantu B, et al. Expanding The Donor Pool For Liver Transplantation. Transpl Int. 2013;26:222.

30. Popescu I. Living donor liver transplantation for hepatocellular carcinoma: defining criteria to extend indications. Dig Dis Sci. 2009;54(2):199-200.

31. Popescu I, Dima SO. Domino liver transplantation: how far can we push the paradigm? Liver Transplant Off Publ Am Assoc Study Liver Dis Int Liver Transplant Soc. 2012;18(1):22-8.

32. Nemes B, Gámán G, Polak WG, Gelley F, Hara T, Ono S, et al. Extended-criteria donors in liver transplantation Part II: reviewing the impact of extended-criteria donors on the complications and outcomes of liver transplantation. Expert Rev Gastroenterol Hepatol. 2016;10(7):841-59.

33. Expanded and Marginal Donors in Liver Transplantation: Need, Use and Results I GST 2016 I Conferenceseries Ltd [Internet]. [cited 2017 May 14]. Available from: http://transplantation.conferenceseries.com/abstract/2016/expanded-and-marginal-donors-in-livertransplantation-need-use-and-results

34. Song KD. Percutaneous cryoablation for hepatocellular carcinoma. Clin Mol Hepatol. 2016;22(4):509-15.

35. Boeti MPS, Popescu I, Grigorie R. Laparoscopic radiofrequency ablation of liver tumors. InTech; 2013.

36. Thomson KR, Cheung W, Ellis SJ, Federman D, Kavnoudias $H$, Loader-Oliver D, et al. Investigation of the Safety of Irreversible Electroporation in Humans. J Vasc Interv Radiol. 2011;22(5): 611-21.

37. Narayanan G, Froud T, Suthar R, Barbery K. Irreversible Electroporation of Hepatic Malignancy. Semin Interv Radiol. 2013;30(1): 67-73.

38. Kudo M. Radiofrequency ablation for hepatocellular carcinoma: updated review in 2010. Oncology. 2010;78 Suppl 1:113-24.

39. Minami $Y$, Kudo M. Radiofrequency Ablation of Hepatocellular Carcinoma: A Literature Review. Int J Hepatol. 2011 11;2011:e104685. 
40. Bruix J, Sherman M, Llovet JM, Beaugrand M, Lencioni R, Burroughs AK, et al. Clinical management of hepatocellular carcinoma. Conclusions of the Barcelona-2000 EASL conference. European Association for the Study of the Liver. J Hepatol. 2001; 35(3):421-30.

41. Zhong J, Ke Y, Gong W, Xiang B, Ma L, Ye X, et al. Hepatic resection associated with good survival for selected patients with intermediate and advanced-stage hepatocellular carcinoma. Ann Surg. 2014;260(2):329-40.

42. Ruzzenente A, Capra F, Pachera S, Iacono C, Piccirillo G, Lunardi M, et al. Is Liver Resection Justified in Advanced Hepatocellular Carcinoma? Results of an Observational Study in 464 Patients. J Gastrointest Surg. 2009;13(7):1313-20.

43. Ishizawa T, Hasegawa K, Aoki T, Takahashi M, Inoue Y, Sano K, et al. Neither multiple tumors nor portal hypertension are surgical contraindications for hepatocellular carcinoma. Gastroenterology. 2008;134(7):1908-16

44. Ho M-C, Huang G-T, Tsang Y-M, Lee P-H, Chen D-S, Sheu J-C, et al. Liver resection improves the survival of patients with multiple hepatocellular carcinomas. Ann Surg Oncol. 2009;16(4):848-55.

45. Ishizaki $Y$, Kawasaki S. The evolution of liver transplantation for hepatocellular carcinoma (past, present, and future). J Gastroenterol. 2008;43(1):18-26.

46. El-Serag HB. Epidemiology of Viral Hepatitis and Hepatocellular Carcinoma. Gastroenterology. 2012:142(6):1264-1273.e1.

47. Yu SJ. A concise review of updated guidelines regarding the management of hepatocellular carcinoma around the world: 20102016. Clin Mol Hepatol. 2016;22(1):7-17.

48. Song P, Tobe RG, Inagaki Y, Kokudo N, Hasegawa K, Sugawara Y, et al. The management of hepatocellular carcinoma around the world: a comparison of guidelines from 2001 to 2011. Liver Int Off J Int Assoc Study Liver. 2012;32(7):1053-63.

49. Omata M, Lesmana LA, Tateishi R, Chen P-J, Lin S-M, Yoshida H, et al. Asian Pacific Association for the Study of the Liver consensus recommendations on hepatocellular carcinoma. Hepatol Int. 2010; 4(2):439-74.

50. Yim HJ. Current management of hepatocellular carcinoma: An Eastern perspective. World J Gastroenterol. 2015;21(13):3826.

51. Kinoshita A, Onoda H, Fushiya N, Koike K, Nishino $H$, Tajiri $H$. Staging systems for hepatocellular carcinoma: Current status and future perspectives. World J Hepatol. 2015;7(3):406-24.

52. Eltawil KM, Kidd M, Giovinazzo F, Helmy AH, Salem RR. Differentiating the impact of anatomic and non-anatomic liver resection on early recurrence in patients with Hepatocellular Carcinoma. World J Surg Oncol. 2010;8:43.

53. Tanaka K, Shimada H, Matsumoto C, Matsuo K, Nagano Y, Endo I, et al. Anatomic versus limited nonanatomic resection for solitary hepatocellular carcinoma. Surgery. 2008;143(5):607-15

54. Gaddikeri S, McNeeley MF, Wang CL, Bhargava P, Dighe MK, Yeh MMC, et al. Hepatocellular Carcinoma in the Noncirrhotic Liver. Am J Roentgenol. 2014;203(1):W34-47.

55. Bhaijee F, Krige JEJ, Locketz ML, Kew MC. Liver resection for noncirrhotic hepatocellular carcinoma in South African patients. South Afr J Surg Suid-Afr Tydskr Vir Chir. 2011;49(2):68-74.

56. Yao FY, Ferrell L, Bass NM, Watson JJ, Bacchetti P, Venook A, et al. Liver transplantation for hepatocellular carcinoma: expansion of the tumor size limits does not adversely impact survival. Hepatol Baltim Md. 2001;33(6):1394-403.

57. McDermott S, Gervais DA. Radiofrequency Ablation of Liver Tumors. Semin Interv Radiol. 2013;30(1):49-55.

58. Chen M-S, Li J-Q, Zheng Y, Guo R-P, Liang H-H, Zhang Y-Q, et al. A Prospective Randomized Trial Comparing Percutaneous Local Ablative Therapy and Partial Hepatectomy for Small Hepatocellular Carcinoma. Ann Surg. 2006;243(3):321-8.

59. Higgins H, Berger DL. RFA for Liver Tumors: Does It Really Work? The Oncologist. 2006;11(7):801-8. 